Original Article

\title{
EXTRACTIVE-SPECTROPHOTOMETRIC DETERMINATION OF SOME ANTIMUSCARINIC ANTAGONIST IN TABLET FORMULATIONS USING ERIOCHROME CYANINE R
}

\author{
AKRAM M. EL-DIDAMONY', MONUIR Z. SAAD, NORA O. SALEEM
}

Chemistry Department, Faculty of Science, Zagazig University, Zagazig 44519, Egypt

Email: ak_eldidamony@yahoo.com

Received: 16 Dec 2017 Revised and Accepted: 24 Feb 2018

\begin{abstract}
Objective: To develop and validate simple, rapid and sensitive spectrophotometric method for the assay of four antimuscarinic antagonists, namely oxybutynin (OXB), solifenacin (SOL), tolterodine (TOL) and fesoterodine (FES) in bulk and pharmaceutical formulations.

Methods: The proposed method is based on the reaction of the selected drugs with eriochrome cyanine R (ECR) in buffered aqueous solution at pH 1.0. The formed ion-pair complexes were extracted with dichloromethane and measured quantitatively with maximum absorption at 464 nm. All variables that affect on color intensity such as $\mathrm{pH}$, buffer volume and concentration of ECR and extractive solvents were studied and optimized.

Results: The calibration graphs were linear over the concentration range of 4-24, 4-32, 4-32 and 2-22 $\mu \mathrm{g} / \mathrm{ml}$ for OXB, SOL, TOL and FES, respectively. The stoichiometry of the reaction was found to be $1: 1$ in all cases. Molar absorptivity values were found to be $2.043 \times 10^{4}, 1.856 \times 10^{4}$, $1.798 \times 10^{4}$ and $2.856 \times 10^{4} \mathrm{l} / \mathrm{mol} / \mathrm{cm}$ for OXB, SOL, TOL and FES, respectively. Excipients which used as an additive in commercial formulations did not interfere in the analysis.
\end{abstract}

Conclusion: The developed method was successfully applied to determine OXB, SOL, TOL and FES in pharmaceutical preparations. The developed method can be used for quality control and routine analysis where time, cost effectiveness and high specificity of analytical technique are of great importance.

Keywords: Spectrophotometry, Ion-pair complexes, Oxybutynin chloride, Solifenacin, Tolterodine, Fesoterodine, Eriochrome cyanine R

(C) 2018 The Authors. Published by Innovare Academic Sciences Pvt Ltd. This is an open access article under the CC BY license (http://creativecommons.org/licenses/by/4.0/) DOI: http://dx.doi.org/10.22159/ijpps.2018v10i4.24300

\section{INTRODUCTION}

Oxybutynin, solifenacin, tolterodine and fesoterodine as an antimuscarinic/anticholinergic muscle relaxant, used to reduce urinary frequency, urinary urgency and urinary incontinence in people with an overactive bladder. They works by relaxing the involuntary detrusor muscle in the wall of the bladder by blocking muscarinic/cholinergic receptors present on the surface of the muscle cells and thus prevents acetylcholine from acting on these receptors [1-4].

Oxybutynin (OXB), ( $\alpha$-cyclohexyl- $\alpha$-hydroxybenzenacetic acid-4(diethylamino)-2-butynyl esters) (fig. 1a) an anticholinergic agents is a tertiary amine that mainly acts as a direct smooth muscle relaxant and displays weak antimuscarinic activity $[5,6]$. A survey of the literature revealed that few methods have been reported for the determination of OXB such as UV and visible spectrophotometry [79], voltammetric [10], HPLC methods [11-14], gas chromatography in serum [15], Polymeric matrix membrane sensors were used for stability-indicating potentiometric determination of OXB and differential pulse polarography [16].

Solifenacin (SOL) [17-20], chemically, is butanedioic acid (3R)-1azabicyclo [2.2.2] octan-3-yl(1S)-1-phenyl-1,2,3,4-tetrahydroisoquinoline-2-carboxylate (fig. 1b), having an empirical formula of $\mathrm{C}_{27} \mathrm{H}_{32} \mathrm{~N}_{2} \mathrm{O}_{6}$ and molecular weight of $480.5528 \mathrm{~g} / \mathrm{mol}$. Literature survey reveals chromatographic methods for the analysis of solifenacin and have been applied for the quantification of SOL in bulk, biological fluids and commercial formulations [21-27]. Though the chromatographic methods are precise the instrumentations are expensive and required critical experimental conditions. Hence these techniques are not applied for routine analysis of SOL. The spectrophotometric methods are still popular for the routine analysis in quality control laboratories because they are precise, simple, fairly accurate and cost-effective. Very few literatures are cited on spectrophotometric methods $[28,29]$.
Tolterodine (TOL) has chemical name of $(-\mathrm{N}, \mathrm{N}$-diisopropyl-3-(2hydroxy-5-methyl phenyl)-3-phenyl-propanamine L-hydrogen tartrate (fig. 1c). The methods reported in the literature for its determination either in biological matrix or in pharmaceutical formulations are spectrophotometric [30-33], LC [34-36], HPLC [37-41], potentiometric [42] and electrochemical methods [43, 44].

Fesoterodine (FES) $[45,46]$ chemically, is designated as isobutyric acid 2-(®-3-diisopropylamino-1-phenylpropyl)-4-hydroxymethyl) phenyl ester hydrogen fumarate (fig. 1d). A survey of chemical literature as shown that few articles are available for the determination of fesoterodine fumarate using LC and LC-MS [4749], HPLC [50-52], UV [53-55] and electrophoresis [56]. An attempt has been made to develop a simple and rapid visible spectrophotometric method for the assay of selected drugs in tablet dosage forms.

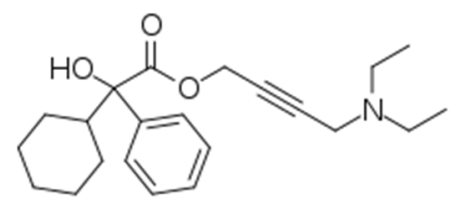

a- OXB [5]

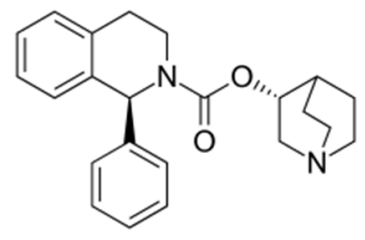

b-

SOL [17] 
<smiles>Cc1ccc(O)c([C@@H](CCN(C(C)C)C(C)C)c2ccccc2)c1</smiles>

c- TOL [38]<smiles>CC(C)C(=O)Oc1ccc(CO)cc1[C@H](CCN(C(C)C)C(C)C)c1ccccc1</smiles>

d- $\quad$ FES [45]

Fig. 1: Chemical structure of the studied drugs

\section{MATERIALS AND METHODS}

\section{Apparatus}

All the absorbance spectral measurements were made using spectroscan 80 D double-beam UV/Visible spectrophotometer (Biotech Engineering Ltd. (UK), with wavelength range $190 \mathrm{~nm} \sim 1100$ $\mathrm{nm}$, spectral bandwidth $2.0 \mathrm{~nm}$, with $10 \mathrm{~mm}$ matched quartz cells.

\section{Reagents and solutions}

All the chemicals were of analytical or pharmaceutical grade and used without further purification. Double distilled de-ionized water was used to prepare all solutions. A stock solution of pure selected drugs was prepared by dissolving $20 \mathrm{mg}$ of the selected drugs in a $100 \mathrm{ml}$ calibrated flask. Working solutions of lower concentrations were freshly prepared by appropriate dilution with water. A $2 \times 10^{\text {- }}$ ${ }^{3} \mathrm{M}$ of eriochrome cyanine $\mathrm{R}$ (ECR) (Sodium 4-[(1-hydroxynaphthalen-2-yl-hydrazinylidene]-7-nitro-3-oxo-Y-naphthalene-1sulfonate) stock solution were prepared by dissolving $107.28 \mathrm{mg}$ of dye (99\% purity) in distilled water and diluting to $100 \mathrm{ml}$ in a measuring flask with distilled water. Series of buffer solutions of $\mathrm{KCl}-\mathrm{HCl}(\mathrm{pH}=1.0-2.2)$, potassium hydrogen phthalate- $\mathrm{HCl}(\mathrm{pH}=2.2-$ $4.0)$ and $\mathrm{NaOAc}-\mathrm{HCl}(\mathrm{pH}=3.2-6.8)$ were prepared by standard methods.
All pharmaceutical preparations were obtained from local market. Tolterodine tablets ( $2 \mathrm{mg}$ TOL/tablet) manufactured by Sabaa International Company for Pharmaceuticals and Chemical Industries, Egypt, Uripan (5 mg OXB/tablet) manufactured by ADWIA Co. S.A.E. $10^{\text {th }}$ of Ramadan City, Egypt, Sofenacin $(5 \mathrm{mg}$ SOL/tablet) manufactured by Marcyrl Pharmaceutical Industries, El Obour City, Egypt and fesoterodine fumarate is Toviaz $4 \mathrm{mg} / \mathrm{tab}$ (Pfizer Company, Egypt).

\section{General recommended procedures}

Into a series of separating funnels, accurately measured aliquots of 4-24 $\mu \mathrm{g} / \mathrm{ml}$ for OXB, 4-32 $\mu \mathrm{g} / \mathrm{ml}$ for SOL, $4-32 \mu \mathrm{g} / \mathrm{ml}$ for TOL and $2-22 \mu \mathrm{g} / \mathrm{ml}$ for FES were pitted out. Then, $2.5 \mathrm{ml}$ of $2 \times 10^{-3} \mathrm{M}$ of ECR, $1.0 \mathrm{ml}$ of buffer solution of $\mathrm{pH}=1.0$ were added and the volume was completed to $10 \mathrm{ml}$ with distilled water. The ion-pairs were extracted with $10 \mathrm{ml}$ of dichloromethane by shaking for $2.0 \mathrm{~min}$ and then, the combined dichloromethane extracts were dried over anhydrous sodium sulphate. The absorbance of colored ion-pair complexes was measured within $20 \mathrm{~min}$ of extraction at $464 \mathrm{~nm}$ against a reagent blank prepared in the same manner except for addition of drugs. A calibration graph was constructed for each drug and the concentration of unknown samples can be deduced by using of calibration graph.

\section{Procedure for tablets}

At least ten tablets of each commercial pharmaceutical formulation of the drugs were weight into a small dish, powdered and mixed well. An accurate weight of the powder equivalent to $10 \mathrm{mg}$ of each drugs was dissolved in distilled water, filtered into a $100 \mathrm{ml}$ calibrated flask and diluted to the mark with water. Further dilution was made to obtain working range concentration and analyzed as the above procedure for the analysis.

\section{RESULTS AND DISCUSSION}

\section{Absorption spectra}

Ion-pair extraction spectrophotometry has received considerable attention for quantitative estimation of many pharmaceutical compounds [57-60]. This technique depends on the reaction of a drug that has basic cationic nitrogen and an anionic dye, where a highly colored ion-pair complex is formed. OXB, SOL, TOL and FES reacted with an anionic dye (ECR) in acidic buffer to form ion-pair complexes, which are soluble in dichloromethane. These complexes have an absorption maximum at $464 \mathrm{~nm}$ against a reagent blank and hence (fig. 2) and this wavelength was used for all subsequent measurements.

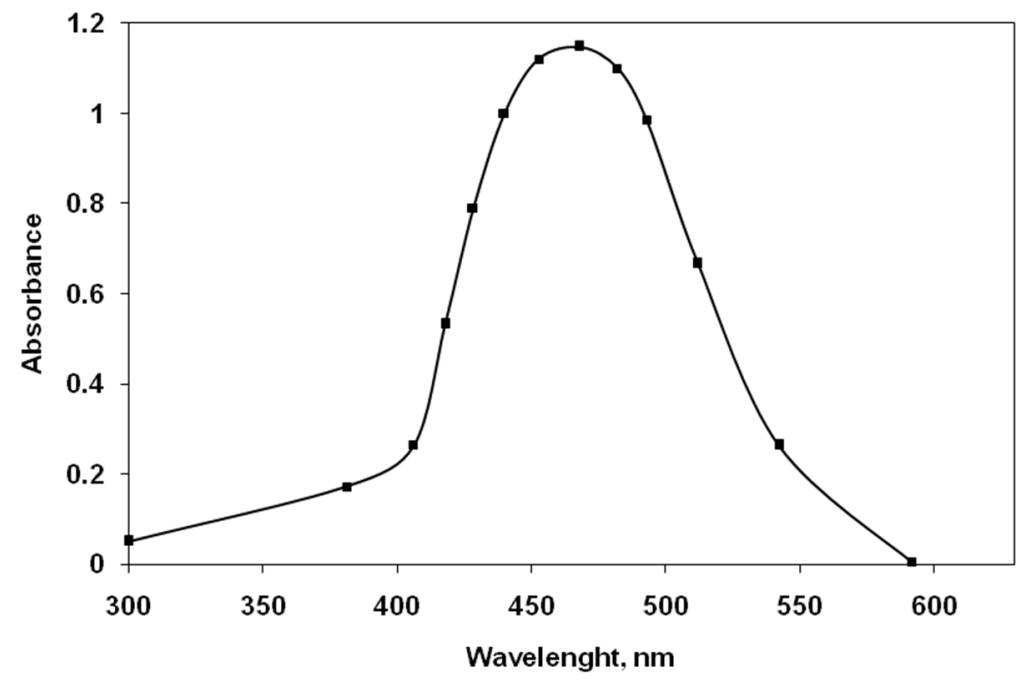

Fig. 2: Absorption spectra of $24 \mu \mathrm{g} / \mathrm{ml}$ OXB with ECR dye complex extracted in dichloromethane 


\section{Optimization of the reaction condition}

The optimization of the methods were carefully studied to achieve complete reaction formation, highest sensitivity and maximum absorbance. Reaction conditions of the ion-pair complexes were found by studying with preliminary experiments such as $\mathrm{pH}$ of the buffer, type of organic solvent, dye concentration and shaking time for the extraction of ion-pair complexes.

\section{Effect of pH}

It was observed that the effective extraction of the complex depends on the type of buffer used and its $\mathrm{pH}$. The effect of $\mathrm{pH}$ was studied by extracting the colored complexes in the presence of various buffers, such as $\mathrm{KCl}-\mathrm{HCl}(\mathrm{pH} 1.0-2.2)$, NaOAc-HCl (pH 1.9-4.92) and NaOAc$\mathrm{AcOH}(\mathrm{pH} 3.4-5.6)$. It was noticed that the maximum color intensity and constant absorbances were observed in $\mathrm{KCl}-\mathrm{HCl}$ of $\mathrm{pH}=1.0$ for all the drugs. The volume of buffer solution added was studied and adding $1.0 \mathrm{ml}$ buffer solution of $\mathrm{pH}=1.0$ attained complete color development. For the highest color intensity and maximum absorbance, the buffer solution should be added after mixing the drug-dye solution at neutral $\mathrm{pH}$.

\section{Choice of organic solvent}

Different organic solvents as dichloromethane, carbon tetrachloride, chloroform and ether were tested as extractive solvents for the proposed method. Dichloromethane was preferred to other solvents for its selective and obtained the highest absorbance with dichloromethane. It was also observed that only one extraction was adequate to achieve a quantitative recovery of the complexes and the shortest time to reach the equilibrium between both phases. Shaking time of $0.5-5$ min provided constant absorbance and hence, 1.0 min was selected as the optimum shaking time.

\section{Effect of dye concentration}

The effect of ECR concentration on the intensity of the color developed at the selected wavelength and constant drugs concentration was tested using different volumes of ECR (0.5-5 ml). It was observed that $2.5 \mathrm{ml}$ of $2 \times 10^{-3} \mathrm{M} \mathrm{ECR}$ were necessary for the maximum color development of the ion-pair complexes. After this volume, the absorbance remains constant by increasing the volume of the reagent.

\section{Sequence of addition and phase ratio}

Although it is not a fundamental factor, the most favorable sequence is drug-reagent-buffer-dichloromethane) for the highest absorbance and stability. The complexes with these sequences remain stable at least for $12 \mathrm{~h}$. The ratio of aqueous to organic phase was ineffective and the ratio 1:1 was chosen for extraction of the colored species.

\section{Stability of the ion-pair complexes}

The stability of the ion-pair complexes formed between the studied drugs and ECR was evaluated. Although the ion-pairs were obtained instantaneously, constant absorbance readings were obtained after not less than $5.0 \mathrm{~min}$ of standing at room temperature $\left(25 \pm 2{ }^{\circ} \mathrm{C}\right)$. Ion-pairs were stable for at least $12 \mathrm{~h}$ without any change in color intensity or in $\lambda_{\max }$.

\section{Composition of ion-pair complexes}

In order to establish a molar ratio between OXB and ECR dyestuff used, Job's method of continuous variation was applied. In this method, solutions of drug and dyestuff with identical molar concentrations were mixed in varying volume ratio in such a way that the total volume of each mixture was the same. The absorbance of each solution was measured and plotted against the mole fraction of the drug. This measurement showed that 1:1 complex was formed through the electrostatic attraction between positive protonated $\mathrm{OXB}^{+}$and negative ECR. The possible reaction mechanism is proposed and given in fig. 3 .

\section{Validation of proposed method}

The following validation parameters were tested according to the guidelines set by the international conference on harmonization (ICH) [61]: linearity, accuracy, precision, limit of detection (LOD) and the limit of quantitation (LOQ).

\section{Linearity and range}

The Beer's law range, molar absorptivity, Sandell's sensitivity, regression equation, slope, intercept and correlation coefficient determined for each drug are given in table 1. A linear relationship was found between the absorbance and the concentration of each drug in the range of $4-24 \mu \mathrm{g} / \mathrm{ml}$ for OXB, $4-32 \mu \mathrm{g} / \mathrm{ml}$ for SOL, $4-32$ $\mu \mathrm{g} / \mathrm{ml}$ for TOL and $2-22 \mu \mathrm{g} / \mathrm{ml}$ for FES (fig. 4). Regression analysis of Beer's law plotted at $\lambda_{\max }$ reveals a good correlation $\left(\mathrm{r}^{2}=0.9976-\right.$ 0.9989 ). The graphs showed a negligible intercept, which was calculated by the least-squares method's regression equation, $\mathrm{A}=$ $\mathrm{a}+\mathrm{bC}$ (where $\mathrm{A}$ is the absorbance of $1.0 \mathrm{~cm}$ layer, $\mathrm{b}$ is the slope, $\mathrm{a}$ is the intercept and $\mathrm{C}$ is the concentration of the measured solution in $\mu \mathrm{g} / \mathrm{ml}$.

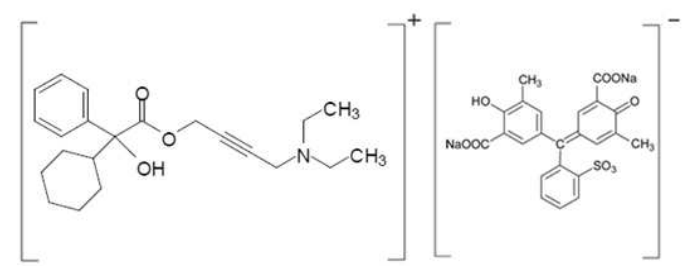

Fig. 3: Structure of OXB-ECR ion pair complex

Table 1: Analytical parameters and optical characteristics of the proposed method

\begin{tabular}{|c|c|c|c|c|}
\hline \multirow[t]{2}{*}{ Parameters } & \multicolumn{4}{|l|}{ Drugs } \\
\hline & OXB & SOL & TOL & FES \\
\hline Beer's law limit, $\mu \mathrm{g} / \mathrm{ml}$ & $4-24$ & $4-32$ & $4-32$ & $2-22$ \\
\hline Molar absorptivity, l/mol/cm & $2.04 \times 10^{4}$ & $1.85 \times 10^{4}$ & $1.79 \times 10^{4}$ & $2.85 \times 10^{4}$ \\
\hline Sandell's sensitivity, $\mathrm{ng} / \mathrm{cm}^{2}$ & 19.27 & 25.88 & 26.44 & 18.47 \\
\hline Correlation coefficient ${ }^{\circledR}$ & 0.9976 & 0.9994 & 0.9989 & 0.9983 \\
\hline \multicolumn{5}{|l|}{ Linear regression equation* } \\
\hline$S_{y / x}$ & 0.0263 & 0.0125 & 0.0143 & 0.0110 \\
\hline Intercept (a) & 0.1499 & 0.2378 & 0.2436 & 0.1556 \\
\hline Slope (b) & 0.0462 & 0.0315 & 0.0301 & 0.0457 \\
\hline SD of slope $\left(S_{b}\right)$ & $1.57 \times 10^{-3}$ & $5.01 \times 10^{-4}$ & $6.05 \times 10^{-4}$ & $1.32 \times 10^{-3}$ \\
\hline SD of intercept $\left(\mathrm{S}_{\mathrm{a}}\right)$ & 0.0540 & 0.0237 & 0.0265 & 0.0227 \\
\hline $\mathrm{LOD}, \mu \mathrm{g} / \mathrm{ml}$ & 0.0357 & 0.0523 & 0.0548 & 0.0361 \\
\hline $\mathrm{LOQ}, \mu \mathrm{g} / \mathrm{ml}$ & 0.1082 & 0.1587 & 0.1661 & 0.1094 \\
\hline
\end{tabular}

OXB: oxybutynin, SOL: solifenacin, TOL: tolterodine, FES: fesoterodine, ${ }^{*} \mathrm{~A}=\mathrm{a}+\mathrm{bc}$, where $\mathrm{A}$ is the absorbance and $\mathrm{C}$ is the concentration of drug in $\mu \mathrm{g} / \mathrm{ml}$. 

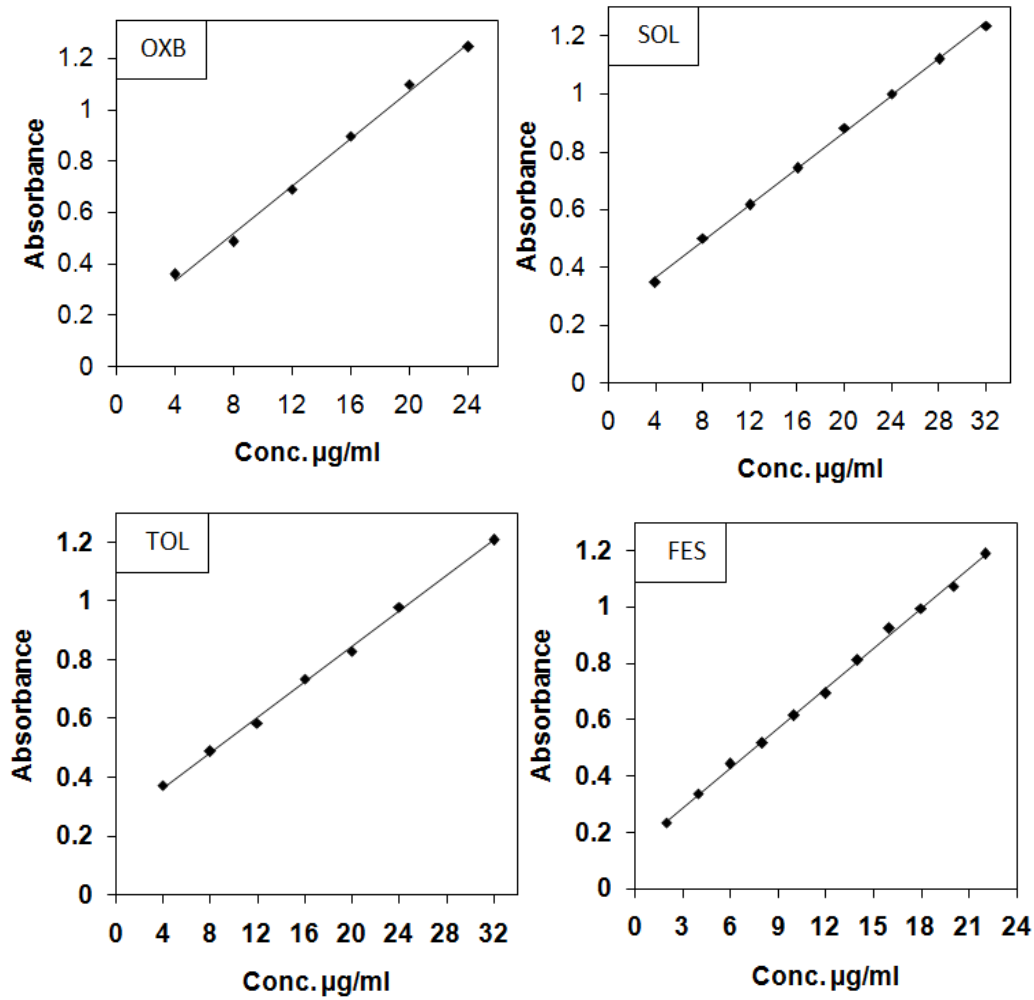

Fig. 4: Calibration curve of ion-pair complexes of OXB, SOL, TOL and FES with ECR against a blank

\section{Detection and quantification limits}

The detection limit (LOD) for the proposed method was calculated using the following equation [61].

$\mathrm{LOD}=3.3 \mathrm{~s} / \mathrm{k}$

Where $\mathrm{s}$ is the standard deviation of replicate determination values under the same conditions as for the sample analysis in the absence of the drug and $\mathrm{k}$ is the sensitivity, namely the slope of the calibration graph. In accordance with the formula, the detection limits obtained for the absorbance were found to be $0.0357 \mu \mathrm{g} / \mathrm{ml}$ for OXB, $0.0523 \mu \mathrm{g} / \mathrm{ml}$ for SOL, $0.0548 \mu \mathrm{g} / \mathrm{ml}$ for TOL and 0.0361 $\mu \mathrm{g} / \mathrm{ml}$ for FES.

The limits of quantification, $\mathrm{LOQ}$, defined as:

$\mathrm{LOQ}=10 \mathrm{~s} / \mathrm{k}$

According to this equation, the limits of quantification were found to be $0.1082 \mu \mathrm{g} / \mathrm{ml}$ for OXB, $0.1587 \mu \mathrm{g} / \mathrm{ml}$ for SOL, $0.1661 \mu \mathrm{g} / \mathrm{ml}$ for TOL and $0.1094 \mu \mathrm{g} / \mathrm{ml}$ for FES. A comparison of the performances between the proposed method and those of reported methods for the studied drugs is summarized in table 2 .
It can be seen that the detection limit of the present work is lower than that found in the reported methods.

\section{Accuracy and precision}

In order to determine the accuracy and precision of the recommended procedure five replicate determinations at three different concentrations of the studied drugs were carried out. Precision and accuracy were based on the calculated relative standard deviation (RSD, \%) and relative error (RE, \%) of the found concentration compared to the theoretical one, respectively (table 3 ) and indicate that the proposed method is highly accurate and reproducible.

\section{Effect of interferences}

In order to evaluate the selectivity of the proposed method for the analysis of pharmaceutical formulations, the effects of the presence of excipients and additives, which can occur in real samples, were investigated. It was found that the presence of the common excipients of tablets such as talc, starch, gelatin, glucose, sulfate, acetate, phosphate and magnesium stearate did not interfere with the determination of the studied drugs at the levels normally found in dosage forms.

Table 2: Comparison of linear range and detection limits for the studied drugs with reported methods

\begin{tabular}{lllll}
\hline Drug & Methods & Linear range, $\boldsymbol{\mu g} / \mathbf{m l}$ & Detection limit, $\boldsymbol{\mu g} / \mathbf{m l}$ & Ref \\
\hline OXB & Squarewave cathodic adsorptive stripping voltammetry & $1-18$ & 0.100 & 10 \\
& Differential pulse cathodic adsorptive stripping voltammetry & $1-17.6$ & 0.2300 & 10 \\
& Ion-association complex with Tropaeoline 000 & $1.0-7.5$ & 0.0621 & 9 \\
& Ion-association complex with Alizarin Red-S. & $2.0-15$ & 0.1112 & 9 \\
& Extractive-spectrophotometric with eriochrome cyanine R & $4-24$ & 0.0357 & Proposed method \\
SOL & HPLC method & $2-100$ & 0.0700 & 22 \\
& RP-HPLC & $20-70$ & 0.100 & 24 \\
& Extractive-spectrophotometric with eriochrome cyanine R & $4-32$ & 0.0523 & Proposed method \\
TOL & Zero order derivative & $30-180$ & 0.6600 & 31 \\
& RP-HPLC & $100-300$ & 0.1600 & 38 \\
FES & Extractive-spectrophotometric with eriochrome cyanine R & $4-32$ & 0.0548 & 56 \\
& Capillary electrophoresis & $2-100$ & 0.5700 & 55 \\
& Second-order derivative UV spectrophotometric & $2-24$ & 0.3800 & 55 \\
& Extractive-spectrophotometric with eriochrome cyanine R & $2-22$ & 0.0227 & Proposed method \\
\hline
\end{tabular}


Table 3: Evaluation of intra-day accuracy and precision of the proposed method

\begin{tabular}{|c|c|c|c|c|c|}
\hline \multirow[t]{2}{*}{ Drugs } & \multicolumn{5}{|c|}{ Intra-day accuracy and precision } \\
\hline & Taken $\mu \mathrm{g} / \mathrm{ml}$ & Found $^{\mathrm{a}} \mu \mathrm{g} / \mathrm{ml}$ & Recovery, \% & RSD, \% & $\mathrm{RE}^{\mathrm{b}}, \%$ \\
\hline \multirow[t]{3}{*}{ OXB } & 4 & 3.9999 & 99.998 & 2.107 & -0.002 \\
\hline & 12 & 11.9995 & 99.996 & 1.527 & -0.004 \\
\hline & 20 & 19.9992 & 99.996 & 1.156 & -0.004 \\
\hline \multirow[t]{3}{*}{ SOL } & 8 & 7.9995 & 99.994 & 1.581 & -0.006 \\
\hline & 20 & 19.998 & 99.994 & 1.703 & -0.006 \\
\hline & 28 & 27.998 & 99.996 & 2.095 & -0.004 \\
\hline \multirow[t]{3}{*}{ TOL } & 8 & 7.9995 & 99.994 & 1.760 & -0.006 \\
\hline & 20 & 19.9988 & 99.994 & 2.059 & -0.006 \\
\hline & 32 & 31.9980 & 99.994 & 1.786 & -0.006 \\
\hline \multirow[t]{3}{*}{ FES } & 4 & 3.9998 & 99.996 & 1.126 & -0.004 \\
\hline & 10 & 9.9994 & 99.994 & 1.393 & -0.006 \\
\hline & 16 & 15.9993 & 99.996 & 1.911 & -0.004 \\
\hline
\end{tabular}

OXB: oxybutynin, SOL: solifenacin, TOL: tolterodine, FES: fesoterodine, aMean value of five determinations, bRE: Relative error.

\section{Tablets analysis}

The proposed method was successfully applied to the determination of OXB, SOL, TOL and FES in their commercially tablets. Various formulations were analyzed to examine the applicability of the developed method and the results were tabulated in table 4 . The results were reproducible with low RSD values. The average percent recoveries obtained were quantitative (95.78-100.73), indicating the good accuracy of the method.

The results of analysis of the commercial tablets and the recovery study of drugs suggested that there is no interference from any excipients (such as starch, talc, gelatin, magnesium stearate, sulfate, glucose, acetate and phosphate), which are present in tablets.

Table 4: Assay results of OXB, SOL, TOL and FES in pharmaceutical formulations by the proposed method

\begin{tabular}{|c|c|c|c|c|c|}
\hline Drug formulations & Drug taken $\mu \mathrm{g} / \mathrm{ml}$ & Drug found ${ }^{\mathrm{a}} \mu \mathrm{g} / \mathrm{ml}$ & Recovery, \% & RSD, \% & $\mathbf{R E}^{\mathrm{b}}, \%$ \\
\hline \multirow[t]{3}{*}{ Uripan tablets ${ }^{c}, 5 \mathrm{mg} / \mathrm{tab}$} & 4 & 3.899 & 97.494 & 2.965 & -2.50 \\
\hline & 12 & 12.051 & 100.430 & 1.442 & 0.43 \\
\hline & 20 & 19.772 & 98.860 & 2.542 & -1.14 \\
\hline \multirow[t]{3}{*}{ sofenacin tablets ${ }^{\mathrm{d}}, 5 \mathrm{mg} / \mathrm{tab}$} & 8 & 7.976 & 99.706 & 3.084 & -0.294 \\
\hline & 20 & 19.878 & 99.392 & 2.329 & -0.608 \\
\hline & 28 & 28.206 & 100.738 & 2.283 & 0.738 \\
\hline \multirow{3}{*}{ Tolterodine tabletse, $2 \mathrm{mg} / \mathrm{tab}$} & 8 & 7.754 & 96.936 & 3.649 & -3.064 \\
\hline & 20 & 19.736 & 98.680 & 2.934 & -1.32 \\
\hline & 32 & 31.107 & 97.210 & 3.655 & -2.79 \\
\hline \multirow[t]{3}{*}{ Toviaz $^{\mathrm{f}}, 4 \mathrm{mg} / \mathrm{tab}$} & 4 & 3.908 & 97.700 & 2.626 & -2.3 \\
\hline & 10 & 9.578 & 95.784 & 3.724 & -4.216 \\
\hline & 16 & 15.796 & 98.726 & 2.039 & -1.274 \\
\hline
\end{tabular}

aMean value of five determinations, bRE: Relative error, cProduced of Adwia pharmaceuticals Company, Egypt, dProduced of Marcyrl Pharmaceutical Industries, Egypt, eProduced of Sabaa international company for Pharmaceutical and chemical industry, Egypt, fProduced of Pfizer Company, Egypt.

\section{CONCLUSION}

The proposed method characterized by using simple reagents which can be afforded by any ordinary analytical laboratory. The method is sufficiently sensitive to permit determination even down to $2.0 \mu \mathrm{g} / \mathrm{ml}$. The developed method is highly reliable owing to the stability of the dye and ion-pair complexes, which are finally measured. The proposed method is simple, precise, accurate and convenient. Therefore, it can be useful for routine analyses and quality control assay of the examined drugs in raw material and in tablets without fear of interference caused by the excipients expected to be present in tablets. This is for the first time that spectrophotometric method is being reported for the assay of FES in pure form and also in its pharmaceutical formulation.

\section{AUTHORS CONTRIBUTIONS}

AKRAM M. EL-DIDAMONY: Developed original idea and design of work. The experimental work was carried out by Nora 0. Saleem, AKRAM M. EL-DIDAMONY, MONUIR Z. SAAD: Data interpretation and manuscript writing. All authors read and approved the final manuscript.

\section{CONFLICT OF INTERESTS}

The authors declare that there are no competing interests.

\section{REFERENCES}

1. Nilvebrant L, Andersson KE, Gillberg PG, Stahl M, Sparf B. Tolterodine-a new bladder-selective antimuscarinic agent. Eur J Pharmacol 1997;327:195-207.
2. Jacquetin B, Wyndaele JJ. Tolterodine reduces the number of urge incontinence episodes in patients with an overactive bladder. Eur J Obstet Gyn RB 2001;98:97-102.

3. Malhotra BK, Glue P, Sweeney K, Anziano R, Mancuso J, Wicker P. Thorough QT study with recommended and supratherapeutic doses of tolterodine. Clin Pharmacol Therap 2007;81:377-85.

4. Diokno AC, Lapides J. Oxybutynin: a new drug with analgesic and anticholinergic properties. J Urol 1972;108:307-9.

5. Lish PM, Labudde JA, Peters EL, Robbins SI. Oxybutynin-a musculotropic antispasmodic drug with moderate anticholinergic action. Arch Int Pharm Ther 1965;156:467-88.

6. Fredericks CM, Anderson GF, Kreulen DL. A study of the anticholinergic and antispasmodic activity of oxybutynin (Ditropan) on rabbit detrusor. Invest Urol 1975;12:317-9.

7. Varma MVS, Kaushal AM, Garg S. Rapid and selective UV spectrophotometric and RP-HPLC methods for dissolution studies of oxybutynin immediate-release and controlledrelease formulations. J Pharm Biomed Anal 2004;36:669-74.

8. Wagieh NE, Hegazy MA, Abdelkawy M, Abdelaleem EA. Quantitative determination of oxybutynin hydrochloride by spectrophotometry, chemometry and HPTLC in presence of its degradation product and additives in different pharmaceutical dosage forms. Talanta 2010;80:2007-15.

9. Srikanth K, Emmanuel KA, Ramesh Raju K. Spectrophotometric determination of oxybutynin chloride through ion-association complex formation. Rasayan J Chem 2010;3:179-87.

10. Jain R, Radhapyari K, Jadon $\mathrm{N}$. Adsorptive stripping voltammetric behavior and determination of anticholinergic 
agent oxybutynin chloride on a mercury electrode. J Colloid Interface Sci 2007;314:572-7.

11. El-Gindy A. High-performance liquid chromatographic determination of oxeladin citrate and oxybutynin hydrochloride and their degradation products. IL Farmaco 2005;60:689-99.

12. da Fonseca P, de Freitas LAP, Pinto LFR, Pestana CR, Bonato PS. Enantioselective analysis of oxybutynin and Ndesethyloxybutynin with application to an in vitro biotransformation study. J Chromatogr B 2008;875:161-7.

13. Guo N, Gao X, Xu G, Guo X. High-performance liquid chromatographic separation of oxybutynin enantiomers using chiral mobile phase additive. Sepu 2008;26:259-61.

14. Ding X, Gao S, Cao Q, Miao C, Zhong Y, Yu Y, et al. Reversedphase high performance liquid chromatographic determination of oxybutynin hydrochloride in its tablets. Dier Junyi Daxue Xuebao 2003;24:327-9.

15. Lindeke B, Brötell H, Karlen B, Rietz G, Vietorisz A. Determination of oxybutynin (4-diethylaminobut-2-ynyl 2cyclohexyl-2-phenylglycolate) in serum and urine by gas chromatography/mass spectrometry with single ion detection. Acta Pharm Suec 1981;18:25-34.

16. Michelitsch A, Likussar W, Schubert-Zsilavecz M. Determination of oxybutynin hydrochloride by differential pulse polarography. Monatsh Chem 1994;125:1183-7.

17. Chapple CR, Arano P, Bosch JL, De Ridder D, Kramer AE, Ridder AM. Solifenacin appears effective and well tolerated in patients with symptomatic idiopathic detrusor overactivity in a placebo-and tolterodine-controlled phase 2 dose-finding study. BJU Int 2004;93:71-7.

18. Cardozo L, Lisec M, Millard R, Van Vierssen, Trip O, Kuzmin I, et al. Randomized, double-blind placebo-controlled trial of the once daily antimuscarinic agent solifenacin succinate in patients with overactive bladder. J Urol 2004;172:1919-24.

19. Ramandeep B, Con K. A review of solifenacin in the treatment of urinary incontinence. Ther Clin Risk Manag 2008;4:117-28.

20. Wagg A, Wyndaele JJ, Sieber P. Efficacy and tolerability of solifenacin in elderly subjects with overactive bladder syndrome: a pooled analysis. Am J Geriatr Pharmacother 2006;4:14-24.

21. Reddy BVR, Reddy BS, Raman NVVSS, Reddy KS, Rambabu C. Development and validation of a specific stability indicating high performance liquid chromatographic methods for related compounds and assay of solifenacin succinate. J Chem 2012;2013:1-10.

22. Desai D, Patel G, Shukla N, Rajput S. Development and validation of stability-indicating HPLC method for solifenacin succinate: isolation and identification of major base degradation product. Acta Chromatogr 2012;24:399-418.

23. Annapurna MM, Sowjanya G, Naidu MS, Lohithasu D. A validated a liquid chromatographic method for the determination of solifenacin succinate (UrinaryAntispasmodic) in tablets. Chem Sci Trans 2014;3:602-7.

24. Kumar RS, kumar BVVR, Kumar PA. A RP-HPLC method development and validation for the estimation of solifenacin in bulk and pharmaceutical dosage forms. Int J Bioassays 2012;1:210-3.

25. Krishna SR, Rao BM, Rao NS. A validated a rapid stabilityindicating method for the determination of related substances in solifenacin succinate by ultra-fast liquid chromatography. J Chromatogr Sci 2010;48:807-10.

26. Vijayasree AV, Anantha kumar AD, Seshagiri Rao BJVLN. Validated RP-HPLC method for the estimation of solifenacin succinate in tablet dosage forms. Pharmanest 2013;4:206-12.

27. Israel DS, Krishnachaitanya K, GowriSankar D. RP-HPLC method for the estimation of tamsulosin and solifenacin in bulk and its dosage forms. Int J Pharm Sci Res 2013;4:4343-50.

28. Teja GD, Dasu CHD, Srinivasa BP, Ravisankar P. Quantitative analysis of solifenacin succinate in pharmaceutical dosage form using UV absorption spectroscopy. J Chem Pharm Sci 2013; 6:195-8

29. Seetharaman R, Lakshmi KS. Development and validation of first-order derivative spectrophotometric method for estimation of solifenacin succinate in a pharmaceutical formulation. Int J Res Pharm Biomed Sci 2011;2:1052-7.
30. Nanda RK, Gaikwad J, Prakash A. Estimation of tamsulosin and tolterodine in its pharmaceutical dosage form by spectrophotometric method. Int J Pharm Tech Res 2009;1:420-3.

31. Shetty SK, Shah A. New spectrophotometric method for estimation of tolterodine in bulk and pharmaceutical formulation. Int J Pharm Sci Res 2011;2:1456-8.

32. Fraihat SM, Khatib HS. Indirect spectrophotometric determination of tolterodine tartrate in pure and pharmaceutical preparations. Asian J Chem 2013;25:1887-90.

33. El-Sheikh R, Hassan WS, Gouda AA, El-Gabry MM. Sensitive spectrophotometric assay of muscarinic receptor antagonist tolterodine tartrate in bulk drug and pharmaceutical formulations. Asian J Pharm Clin Res 2017;10:346-52.

34. Madhavi A, Reddy GS, Suryanarayana VM, Naidu A. A development and validation of a new analytical method for the determination of related components in tolterodine tartarate using LC. Chromatographia 2008;86:399-407.

35. Macek J, Ptacek P, Klima J. Determination of tolterodine and its 5-hydroxymethyl metabolite in human plasma by hydrophilic interaction liquid chromatography-tandem mass spectrometry. J Chromatogr B 2009;877:968-74.

36. Yadav M, Upadhyay V, Chauhan V, Solanki G, Jani A, Baxi GA, et al. LC-MS-MS Separation and simultaneous determination of tolterodine and its active metabolite, 5-Hydroxymethyl tolterodine in human plasma. Chromatographia 2010;72:255-64.

37. Siddartha B, Sudheer Babu I, Racichandra Gupta Ch, Parthiban C. Analytical method development and validation for simultaneous estimation of tamsulosin and tolterodine in bulk and pharmaceutical dosage form by the RP-HPLC method. Asian J Pharm Clin Res 2014;7:156-60.

38. Xia ZL, Chen ZY, Yao TW. An enantiospecific HPLC method for the determination of (S)-enantiomer impurities in (R)tolterodine tartarate. Pharmazie 2007;62:170-3.

39. Radhakrishna S, Rao BM, Rao NS. A validated stabilityindicating HPLC method for the determination of related substances and assay of tolterodine tartarate. Rasáyan J Chem 2009;2:144-50.

40. Sinha VR, Jindal V, Kumar RV, Bhinge JR, Goel H. Development and validation of a simple, stability-indicating highperformance liquid chromatographic method for analysis of tolterodine tartrate in the bulk drug and in its tablet formulation. Acta Chromatogr 2011;23:133-43.

41. Ramathilagam N, Meeradevi M, Solairaj P, Rajesh SC. Development and validation of HPLC method for the estimation of tolterodine tartrate in tablets. Int J Pharm Biol Sci 2012;2:332-7.

42. Sakra MM, Nashara RM. Potentiometric determination of tolterodine in batch and flow injection conditions. Talanta 2012;96:153-60.

43. Macikova P, Skopalova J, Cankar P, Papouskova B, Strakova R, Jirovsky $\mathrm{D}$, et al. Electrochemical oxidation of tolterodine. Electroanalysis 2013;25:205-12.

44. Kul D. Sensitive and selective determination of tolterodine tartrate and its electrochemical investigation on solid carbon based electrodes. J Anal Chem 2014;69:970-81.

45. Dmochowski RR, Gomelsky A. Update on the treatment of overactive bladder. Curr Opin Urol 2011;21:286-90.

46. Wyman JF, Burgio KL, Newman DK. Practical aspects of lifestyle modifications and behavioral interventions in the treatment of overactive bladder and urgency urinary incontinence. Int J Clin Pract 2009;63:1177-91.

47. Sangoi MS, Steppe M. Determination of fesoterodine in pharmaceutical formulations by using liquid chromatographytandem mass spectrometry. Eur J Mass Spectrom 2010;16:65361.

48. Sangoi MS, Todeschini V, Steppe M. Fesoterodine stress degradation behavior by liquid chromatography coupled ultraviolet detection and electrospray ionization mass spectrometry. Talanta 2011;84:1068-79.

49. Parekh JM, Sanyal M, Yadav M, Shrivastav PS. Investigation of ex vivo stability of fesoterodine in human plasma and its simultaneous determination together with its active metabolite 5-HMT by LC-ESI-MS/MS: application to a bioequivalence study. J Chromatogr B 2013;913:1-11. 
50. Reddy BVR, Reddy BS, Kumar MS, Rambabu C. A validated stability-indicating HPLC assay method for determination of fesoterodine fumarate. Rasáyan J Chem 2012;5:239-45.

51. Kotla NR, Nagaraju ChVS, Rajan ST, Eshwaraiah S, Sampath KRG, Rakesh M, et al. Stability indicating HPLC method for the quantification of fesoterodine fumarate and its related substances. Pharma Chem 2013;5:115-22.

52. Rajput AP, Sonanis MC. Stability indicating HPLC method for the enantiomeric separation of fesoterodine fumarate in drug product and drug substance using chiral stationary phase. J Chem Pharm Res 2012;4:4127-33.

53. Satya T, Yadav GKSS, Chakravarthy IE. New simple UV spectrophotometric determination of paliperidone palmitate in tablets. Int J Eng Sci Res Technol 2014;3:411-3.

54. Thotteti S, Yadav SS, Chakravarthy IE. A simple UV spectrophotometric method for the determination of fesoterodine fumarate in tablets. Int J Pharm Sci Lett 2014;4:413-6.

55. Sangoi MS, Todeschini V, Steppe M. Second-order derivative uv spectrophotometric method for the determination of fesoterodine and comparison with LC, CE and LC-MS/MS in commercial extended-release tablets. Acta Chim Slov 2012;59:136-43.
56. Sangoi MS, Todeschini V, Steppe M. Determination of fesoterodine in a pharmaceutical preparation by a stabilityindicating capillary zone electrophoresis method. J AOAC Int 2013;96:1308-14.

57. El-Didamony AM. Extractive spectrophotometric methods for the determination of oxomemazine hydrochloride in bulk and pharmaceutical formulations using bromocresol green, bromocresol purple and bromophenol blue. Arch Der Pharmazie 2005;338:190-7.

58. El-Didamony AM. Spectrophotometric determination of benzydamine $\mathrm{HCl}$, levamisole $\mathrm{HCl}$ and mebeverine $\mathrm{HCl}$ through ion-pair complex formation with methyl orange. Spectrochim Acta A 2008;69:770-5.

59. El-Didamony AM, Mustafa MA. Spectrophotometric determination of diphenhydramine hydrochloride in pharmaceutical preparations and biological fluids via ion-pair formation. Arab J Chem 2010;3:265-70.

60. El-Didamony AM, Shehata AM. Spectrophotometric determination of $\beta$-adrenergic antagonists drugs via ion-pair complex formation using MO and EBT. Opt Spectrosc 2014;117:492-9.

61. Miller JC, Miller JN. "Significance tests in statistics for analytical chemistry", 3rd ed. Chap. 3. Hardwood, Chichester; 1993. 